\title{
Targeted temperature management for adult out-of-hospital cardiac arrest: current concepts and clinical applications
}

Tatsuma Fukuda

\begin{abstract}
Targeted temperature management (TTM) (primarily therapeutic hypothermia (TH)) after out-of-hospital cardiac arrest (OHCA) has been considered effective, especially for adult-witnessed OHCA with a shockable initial rhythm, based on pathophysiology and on several clinical studies (especially two randomized controlled trials (RCTs) published in 2002). However, a recently published large RCT comparing $T M$ at $33^{\circ} \mathrm{C}(\mathrm{TH})$ and $T \mathrm{M}$ at $36{ }^{\circ} \mathrm{C}$ (normothermia) showed no advantage of $33^{\circ} \mathrm{C}$ over $36^{\circ} \mathrm{C}$. Thus, this RCT has complicated the decision to perform TH after cardiac arrest. The results of this RCT are sometimes interpreted fever control alone is sufficient to improve outcomes after cardiac arrest because fever control was not strictly performed in the control groups of the previous two RCTs that showed an advantage for TH. Although this may be possible, another interpretation that the optimal target temperature for $\mathrm{TH}$ is much lower than $33^{\circ} \mathrm{C}$ may be also possible. Additionally, there are many points other than target temperature that are unknown, such as the optimal timing to initiate $T T M$, the period between $\mathrm{OHCA}$ and initiating TTM, the period between OHCA and achieving the target temperature, the duration of maintaining the target temperature, the TTM technique, the rewarming method, and the management protocol after rewarming. RCTs are currently underway to shed light on several of these underexplored issues. In the present review, we examine how best to perform TTM after cardiac arrest based on the available evidence.
\end{abstract}

Keywords: Out-of-hospital cardiac arrest, Cardiopulmonary resuscitation, Post-cardiac arrest syndrome, Targeted temperature management, Therapeutic hypothermia

\section{Introduction}

The 2010 International Consensus on Cardiopulmonary Resuscitation and Emergency Cardiovascular Care Science with Treatment Recommendations (CoSTR) from the International Liaison Committee on Resuscitation (ILCOR) recommends therapeutic hypothermia $(\mathrm{TH})\left(32-34{ }^{\circ} \mathrm{C}\right.$ for $12-24 \mathrm{~h}$ ) for comatose adult patients upon return of spontaneous circulation (ROSC) after out-of-hospital cardiac arrest (OHCA) with a shockable initial rhythm. It also states that $\mathrm{TH}$ may be considered for OHCA with a non-shockable initial rhythm or in-hospital cardiac arrest $[1,2]$. This recommendation was based on two landmark randomized controlled trials (RCT) published in 2002 and supported by various subsequent

Correspondence: tatsumafukuda-jpn@umin.ac.jp

Department of Emergency and Critical Care Medicine, Graduate School of Medicine, The University of Tokyo, 7-3-1, Hongo, Bunkyo-ku, Tokyo 113-8655, Japan studies [3-6]. However, a recently published large RCT raised questions about the effect of $\mathrm{TH}$ because that RCT showed no advantage for TH compared with normothermia (or fever control) [7].

In this review, we examine whether $\mathrm{TH}$ is beneficial after cardiac arrest and how best to perform targeted temperature management (TTM) after cardiac arrest on the basis of current evidence.

\section{Review}

Rationale for TTM

There are three distinct phases of brain injury in cardiac arrest $[8,9]$. The first phase is intra-arrest ischemic injury due to no flow. In this phase, energy failure, ischemic depolarization of cell membranes, release of excitatory amino acids, and cytosolic calcium overload occur. Irreversible injury can be caused by them when ischemia is prolonged. The second phase is immediate reperfusion 
injury caused after ROSC. The resumption of oxidative phosphorylation can lead to reactive oxygen species production, mitochondrial calcium overload, and mitochondrial permeability transition, triggering cell death signaling. The third phase is delayed post-reperfusion injury. Secondary neuronal calcium overload, activation of pathologic protease, and altered gene expression and inflammation can occur and can last for several days. All three of these phases are potential targets for TTM.

Based on pathophysiological studies, hypothermia is believed to elicit neurological protection in multiple ways. Hypothermia decreases cerebral blood flow and cerebral oxygen consumption approximately by $7-8 \%$ per $1{ }^{\circ} \mathrm{C}$ decline in temperature $[10,11]$. Decreased cerebral metabolism protects the brain from further injury after anoxic injury $[12,13]$. In addition, hypothermia affects two apoptotic cell death pathways. One is the intrinsic pathway under mitochondrial control, and the other is the extrinsic pathway signaled by an extracellular receptor [14]. Moreover, hypothermia reduces inflammation and free radical production [15]. Hypothermia can also prevent brain edema caused by blood-brain barrier disruption and increased vascular permeability following ischemia-reperfusion injury $[16,17]$.

Based on clinical studies, hypothermia was considered to improve outcomes after cardiac arrest. Two major RCTs that provided evidence of a benefit of $\mathrm{TH}$ were published in 2002 [3, 4].

In the European RCT, 275 adult comatose survivors after witnessed OHCA of presumed cardiac origin with shockable initial rhythm were enrolled [3]. Patients were randomly assigned to receive TTM (or TH) (target temperature, $32-34{ }^{\circ} \mathrm{C}$; timing of initiation, at hospital after ROSC; treatment duration, $24 \mathrm{~h}$ from the start of cooling) or standard treatment with normothermia (Table 1). TTM group had more favorable neurological outcome (Glasgow-Pittsburgh cerebral performance category (CPC) of 1 or 2) within 6 months after OHCA than normothermia group (55 vs. $39 \%$; relative risk (RR), 1.40; $95 \%$ confidence interval (CI), 1.08-1.81). In addition, 6month mortality was lower in the TTM group than in the normothermia group ( 41 vs. $55 \%$; RR, 0.74; $95 \%$ CI, 0.580.95). In this study, the body temperature of the normothermia group was not strictly managed. Therefore, the average body temperature in the normothermia group reached almost $38^{\circ} \mathrm{C}$ because of the lack of fever control.

In the Australian RCT, 77 adult comatose survivors after OHCA with shockable rhythm were enrolled [4]. Patients enrolled on odd-numbered days of the month were assigned to TTM (or TH) (target temperature, $33^{\circ} \mathrm{C}$; timing of initiation, in ambulance after ROSC; treatment duration, $12 \mathrm{~h}$ after hospital arrival), and patients enrolled on even-numbered days of the month were assigned to normothermia (Table 1). The TTM group had more favorable neurological outcomes at discharge from hospital than the normothermia group ( 49 vs. $26 \%$; $P=$ 0.046). After adjustment for age and time from collapse to ROSC, the odds ratio (OR) for a favorable neurological outcome with TTM compared to normothermia was 5.25 (95 \% CI, 1.47-18.76; $P=0.011$ ). In this study, the body temperature of the normothermia group was relatively successfully maintained at $37.0{ }^{\circ} \mathrm{C}$. However, the process of the randomization was inadequate because of the assignment in accordance with the day of the month, with patients assigned to hypothermia on odd-numbered days.

Although these two RCTs were not flawless, they are the basis for clinical practice guidelines that recommend $\mathrm{TH}$ after cardiac arrest issued by various organizations such as the American Heart Association (AHA), the European Resuscitation Council (ERC), and the Neurocritical Care Society (NCS) (Table 1) [18-20]. A Cochrane systematic review also supported these recommendations [5].

However, a large RCT published in 2013 has raised questions about the benefit of TH [7]. In this large RCT, 939 unconscious adult survivors after OHCA of presumed cardiac cause were enrolled irrespective of initial rhythm. Patients were randomly assigned to receive TTM of $33^{\circ} \mathrm{C}$ (or $\mathrm{TH}$ ) (target temperature, $33{ }^{\circ} \mathrm{C}$; timing of initiation, at hospital after ROSC; treatment duration, $28 \mathrm{~h}$ from randomization) or TTM of $36{ }^{\circ} \mathrm{C}$ (or normothermia with strict fever control) (Table 1). At the end of the trial, the mortality rates in both groups were similar (50 vs. $48 \%$; hazard ratio (HR) with a temperature of $33{ }^{\circ} \mathrm{C}, 1.06$; $95 \%$ CI $0.89-1.28 ; P=0.51)$. At the 180 -day follow-up, neurological outcomes were also similar in both groups, according to a CPC of 3-5 (54 vs. $52 \%$; RR, 1.02; $95 \%$ CI 0.88-1.16; $P=0.78$ ) or a modified Rankin scale of $4-6$ (52 vs. $52 \%$; RR, 1.01; $95 \%$ CI $0.89-1.14 ; P=0.87)$. The authors concluded that TTM of $33^{\circ} \mathrm{C}$ did not confer any benefit for unconscious survivors after OHCA relative to TTM of $36^{\circ} \mathrm{C}$.

TTM study makes it difficult to judge whether outcomes after OHCA are improved by hypothermia. However, TTM study and previous two RCTs differed not only in their implementation of strict fever control in the control group but also in some other details (Table 1). Therefore, the details of practical methods for TTM should also be examined.

\section{Practical methods for TTM}

There are three phases in TTM (mainly TH): induction, maintenance, and rewarming. Unsolved issues remain in each phase, including the appropriate target temperature, the timing of initiation, the duration from cardiac arrest to initiation of TTM or the achievement of target temperature, the treatment duration, the TTM technique, and the rewarming method (Fig. 1). 
Table 1 Differences in detailed targeted temperature management protocol between guidelines and randomized controlled trials

\begin{tabular}{|c|c|c|c|c|c|c|c|c|c|}
\hline $\begin{array}{l}\text { Authors } \\
\text { (published } \\
\text { year) }\end{array}$ & $\begin{array}{l}\text { Target } \\
\text { temperature }\end{array}$ & $\begin{array}{l}\text { Timing of } \\
\text { initiation }\end{array}$ & $\begin{array}{l}\text { Time to target } \\
\text { temperature }\end{array}$ & Cooling techniques & $\begin{array}{l}\text { Treatment } \\
\text { duration }\end{array}$ & Sedatives & $\begin{array}{l}\text { Neuromuscular } \\
\text { blockades }\end{array}$ & Rewarming methods & $\begin{array}{l}\text { Management after } \\
\text { rewarming }\end{array}$ \\
\hline $\begin{array}{l}\text { HACA Study } \\
\text { Group } 2002 \text { [3] }\end{array}$ & $32-34^{\circ} \mathrm{C}$ & $\begin{array}{l}\text { After ROSC } \\
\text { at hospital }\end{array}$ & $\begin{array}{l}\text { Within } 4 \mathrm{~h} \\
\text { after ROSC }\end{array}$ & $\begin{array}{l}\text { External cooling } \\
\text { device }\left(\text { TheraKool }{ }^{\oplus}\right) \\
\text { (if the goal was not } \\
\text { achieved, ice packs } \\
\text { were applied }\end{array}$ & $\begin{array}{l}24 \mathrm{~h} \text { from } \\
\text { cooling }\end{array}$ & $\begin{array}{l}\text { Midazolam } \\
(0.125 \mathrm{mg} / \mathrm{kg} / \mathrm{h}) \\
\text { and fentanyl } \\
\text { (0.002 mg/kg/h) } \\
\text { for } 32 \mathrm{~h}\end{array}$ & $\begin{array}{l}\text { Pancuronium } \\
(0.1 \mathrm{mg} / \mathrm{kg}) \\
\text { every } 2 \mathrm{~h} \text { for a } \\
\text { total of } 32 \mathrm{~h}\end{array}$ & $\begin{array}{l}\text { Passive rewarming } \\
\text { (over a period of } 8 \mathrm{~h} \text { ) }\end{array}$ & I \\
\hline $\begin{array}{l}\text { Bernard, et al. } \\
2002[4]\end{array}$ & $33^{\circ} \mathrm{C}$ & $\begin{array}{l}\text { After ROSC in } \\
\text { the ambulance }\end{array}$ & / & $\begin{array}{l}\text { Ice packs } \\
\left(\text { Coolcare }{ }^{\oplus}\right)\end{array}$ & $\begin{array}{l}12 \mathrm{~h} \text { after } \\
\text { hospital arrival }\end{array}$ & $\begin{array}{l}\text { Midazolam } \\
(2-5 \mathrm{mg}) \text { for } \\
24 \mathrm{~h}\end{array}$ & $\begin{array}{l}\text { Vecronium } \\
(8-12 \mathrm{mg}) \text { for } \\
24 \mathrm{~h}\end{array}$ & $\begin{array}{l}\text { Beginning at } 18 \mathrm{~h} \text {, } \\
\text { actively rewarmed for } \\
\text { the next } 6 \mathrm{~h} \text { by external } \\
\text { warming with a heated-air } \\
\text { blanket }\end{array}$ & Usual intensive care \\
\hline $\begin{array}{l}\text { CoSTR from } \\
\text { ILCOR } 2010[1,2] \\
\text { Guidelines from } \\
\text { AHA, ERC } 2010[18,19]\end{array}$ & $32-34^{\circ} \mathrm{C}$ & $\begin{array}{l}\text { Minutes to } \\
\text { hours after } \\
\text { ROSC }\end{array}$ & / & $\begin{array}{l}\text { No single methods } \\
\text { has proved to be } \\
\text { optimal }\end{array}$ & $12-24 h$ & / & / & / & $\begin{array}{l}\text { Late hyperthermia (after } \\
\text { rewarming post-hypothermia) } \\
\text { should be identified and } \\
\text { treated }\end{array}$ \\
\hline $\begin{array}{l}\text { Nielsen, et al. } \\
2013 \text { [7] }\end{array}$ & $33^{\circ} \mathrm{C}$ & $\begin{array}{l}\text { After } \\
\text { randomization } \\
\text { at hospital, } \\
\text { after ROSC }\end{array}$ & $\begin{array}{l}\text { As rapidly } \\
\text { as possible }\end{array}$ & $\begin{array}{l}\text { Ice-cold fluids, } \\
\text { ice packs, and } \\
\text { intravascular or } \\
\text { surface temperature- } \\
\text { management } \\
\text { devices at the } \\
\text { discretions of the } \\
\text { sites }\end{array}$ & $\begin{array}{l}28 \mathrm{~h} \text { after } \\
\text { randomization }\end{array}$ & $\begin{array}{l}\text { Mandated until } \\
\text { the end of the } \\
\text { intervention } \\
\text { period ( } 36 \mathrm{~h} \text { ) }\end{array}$ & l & $\begin{array}{l}\text { After } 28 \mathrm{~h} \text {, gradual } \\
\text { rewarming to } 37^{\circ} \mathrm{C} \\
\left(0.5^{\circ} \mathrm{C} / \mathrm{h}\right)\end{array}$ & $\begin{array}{l}\text { For unconscious patients } \\
\text { below } 37.5^{\circ} \mathrm{C} \text { until } 72 \mathrm{~h} \text { after } \\
\text { cardiac arrest, with the use of } \\
\text { fever control measures at the } \\
\text { discretion of the sites }\end{array}$ \\
\hline
\end{tabular}

/ not described 


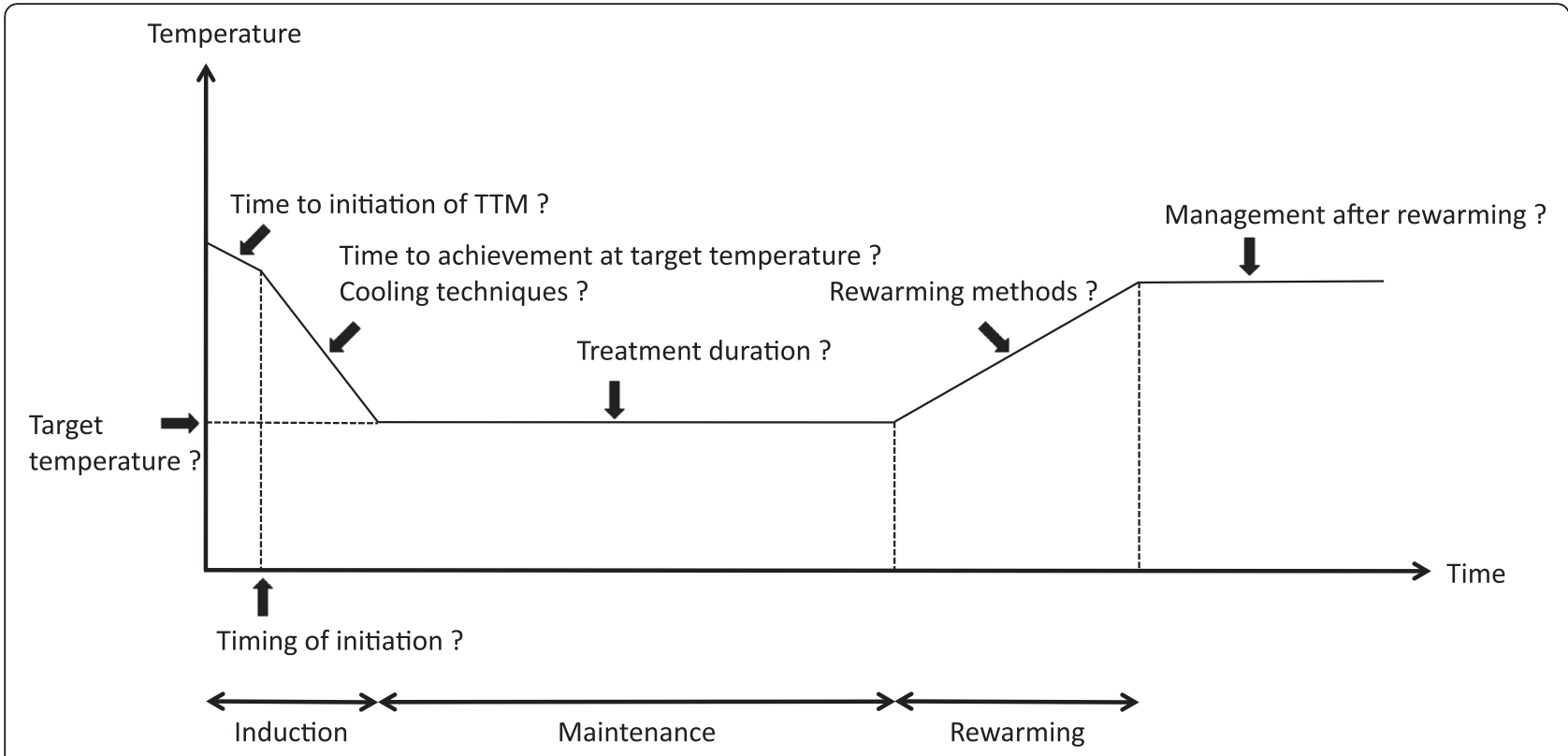

Fig. 1 Time course of targeted temperature management

\section{Target temperature}

The optimal target temperature for neurologically favorable outcomes after OHCA is unclear at this time. Although mild hypothermia $\left(32-34{ }^{\circ} \mathrm{C}\right)$ has been strongly recommended by various organizations on the basis of the two RCTs published in 2002, several subsequent studies, and pathophysiological findings, the recently published RCT comparing TTM of $33{ }^{\circ} \mathrm{C}$ with TTM of $36{ }^{\circ} \mathrm{C}$ showed no beneficial effect of mild hypothermia compared with normothermia (with strict fever control) [1-7, 10-19]. This could mean that strict fever control alone may be sufficient to improve neurological outcomes among OHCA compared with mild hypothermia, or that the optimal target temperature may be lower than $33{ }^{\circ} \mathrm{C}$. However, the differences in the main results of the three RCTs that compared TH with normothermia may be caused by differences in their implementations of TTM other than the target temperature (Table 1). To determine the optimal target temperature for improving neurological outcomes after OHCA, further study will be required; comparing a range of target temperature levels without varying other aspects of TTM. An RCT comparing TTM at $31{ }^{\circ} \mathrm{C}$ and TTM at $34{ }^{\circ} \mathrm{C}$ (CAPITAL CHILL (NCT02011568)) is currently recruiting, and it may provide further clarification.

\section{Timing of initiation and duration from cardiac arrest to initiation or target temperature}

The optimal timing for initiating TTM is unknown. In addition, the effect on outcomes of delay between the onset of cardiac arrest and initiating TTM or achieving the target temperature is not well understood.
Animal experiments have shown that earlier initiation of TH increases the efficacy of TH $[21,22]$ and that survival rates are high and brain injury is mild when $\mathrm{TH}$ is initiated during the intra-arrest period before ROSC [23, 24 ]. However, similar results have not always been obtained in studies involving human subjects. A registry study in Scandinavia including $986 \mathrm{TH}$-treated OHCA patients, the largest-scale study of this issue, did not reveal any relationship between neurologic outcomes and the length of time from cardiac arrest until the initiation of TH (median $90 \mathrm{~min}, p=0.48$ ) or until the target temperature was achieved (median $260 \mathrm{~min}, p=0.91$ ) [6]. However, according to a study in the USA using data from the International Cardiac Arrest Registry (INTCAR), which included $172 \mathrm{OHCA}$ patients treated with $\mathrm{TH}$, every 5-min delay in initiating $\mathrm{TH}$ (mean $94.4 \mathrm{~min}$ ) was associated with a worsening in neurologic outcomes at intensive care unit (ICU) discharge (OR 1.06, 95 \% CI 1.021.10), at hospital discharge (OR 1.06, 95 \% CI 1.02-1.11), and 1 month after hospital discharge (OR 1.08, $95 \% \mathrm{CI}$ 1.03-1.13) [25]. Furthermore, neurologic outcomes 1 month after discharge worsened with every 30-min delay in achieving the target temperature (OR 1.17, $95 \%$ CI 1.01-1.36). In another study in the USA, which included 140 OHCA patients who had achieved ROSC, a $20 \%$ increase in the risk of death (95\% CI 4-39\%) was observed for every hour of delay in initiation of $\mathrm{TH}$ [26]. In a study in Germany that included 49 successfully resuscitated OHCA and in-hospital cardiac arrest (IHCA) patients, neurologic outcomes worsened for every hour delay in reaching the target temperature (OR 0.69, $95 \%$ CI 0.51-0.98) [27]. It is necessary to note that 
comparatively long delays, approximately $80-150 \mathrm{~min}$ from cardiac arrest to initiation of $\mathrm{TH}$ and approximately 260-410 min from cardiac arrest to achievement of target temperature, were observed in these studies.

Several studies have examined the feasibility, safety, and efficacy of pre-hospital $\mathrm{TH}$ with the purpose of more quickly initiating $\mathrm{TH}$ and achieving the target temperature. The safe and effective introduction of $\mathrm{TH}$ appears to be feasible not only after ROSC [28-31] but also before ROSC (intra-arrest or during resuscitation) [32, 33].

There have been many RCTs investigating the relationship between pre-hospital TH after ROSC and outcomes after OHCA [34-36], and meta-analyses have also been conducted $[37,38]$. In all studies, pre-hospital TH decreased core temperature on hospital arrival and reduced the time to target temperature, but improvements in survival rates and neurologic outcomes were not shown.

Animal experiments and clinical studies have shown decreases in myocardial infarction size and increases in ROSC rates when TH was initiated before ROSC (intraarrest) $[39,40]$, and a systematic review showed that, although clinical data are limited, intra-arrest TH improved not only ROSC rates but also survival rates and favorable neurologic outcomes [41]. Two large RCTs examining pre-hospital intra-arrest $\mathrm{TH}$ by intranasal cooling (PRINCESS (NCT01400373)) or by rapid infusion of cold normal saline (RINSE (NCT01173393)) are ongoing.
Although there is currently little evidence supporting earlier initiation of pre-hospital $\mathrm{TH}$ after ROSC, its introduction before ROSC may be effective; thus, the results of the RCTs currently in progress will provide important clarification.

\section{Treatment duration}

The 2010 AHA guidelines states that the optimal duration of $\mathrm{TH}$ is at least $12 \mathrm{~h}$ and may be more than $24 \mathrm{~h}$ [18]. This recommendation is based on two RCTs that showed beneficial effects of $\mathrm{TH}$ for adult OHCA with a shockable initial rhythm $[3,4]$. Although TH for up to $72 \mathrm{~h}$ has been used safely in newborns, the effect of longer $\mathrm{TH}$ duration on outcomes for adult OHCA has not been studied [42, 43]. An RCT of prolonged TH (at $32-34{ }^{\circ} \mathrm{C}$ for 24 vs. $48 \mathrm{~h}$ ) (TTH48 (NCT01689077)) is now recruiting, and it may provide further information.

\section{TTM techniques}

Common methods used for cooling include rapid infusion of ice-cold IV fluid, ice packs, water-circulating blankets, air-circulating blankets, water-circulating gelcoated pads, and intravascular cooling devices (Table 2). Moreover, there are methods that use cardiopulmonary bypass [44], nasopharyngeal cooling [45], transnasal evaporative cooling [33, 46], cold-air tents [3], and cooling helmets $[47,48]$, among others. The CoSTR from ILCOR

Table 2 Cooling techniques

\begin{tabular}{|c|c|c|c|c|c|}
\hline & $\begin{array}{l}\text { Rapid infusion of ice-cold IV } \\
\text { fluid and ice packs }\end{array}$ & $\begin{array}{l}\text { Water-circulating } \\
\text { blankets }\end{array}$ & $\begin{array}{l}\text { Air-circulating } \\
\text { blankets }\end{array}$ & $\begin{array}{l}\text { Water-circulating } \\
\text { gel-coated pads }\end{array}$ & Intravascular cooling devices \\
\hline \multicolumn{6}{|l|}{ Induction phase } \\
\hline \multicolumn{6}{|l|}{ Simpleness } \\
\hline Pre-hospital & O & $\times$ & $x$ & $x$ & $x$ \\
\hline \multirow[t]{2}{*}{ After hospital arrival } & O & $\triangle$ & $\triangle$ & $\triangle$ & $x$ \\
\hline & & Specialized devices & Specialized devices & Specialized devices & $\begin{array}{l}\text { Specialized devices } \\
\text { intravascular catheterization }\end{array}$ \\
\hline \multirow[t]{2}{*}{ Non-invasiveness } & O & ○ & O & ○ & $x$ \\
\hline & & & & & intravascular catheterization \\
\hline \multirow[t]{2}{*}{ Cooling rate } & $\times$ & O & $x$ & O & O \\
\hline & $0.32 \pm 0.24^{\circ} \mathrm{C} / \mathrm{h}$ & $1.33 \pm 0.63^{\circ} \mathrm{C} / \mathrm{h}$ & $0.18 \pm 0.20^{\circ} \mathrm{C} / \mathrm{h}$ & $1.04 \pm 0.14^{\circ} \mathrm{C} / \mathrm{h}$ & $1.46 \pm 0.42^{\circ} \mathrm{C} / \mathrm{h}$ \\
\hline \multicolumn{6}{|l|}{ Maintenance phase } \\
\hline \multirow[t]{2}{*}{ Stability ${ }^{a}$} & $x$ & $x$ & $\times$ & $x$ & ० \\
\hline & $69.8 \pm 37.6 \%$ & $50.5 \pm 35.9 \%$ & $74.1 \pm 40.5 \%$ & $44.2 \pm 33.7 \%$ & $3.2 \pm 4.8 \%$ \\
\hline \multirow[t]{2}{*}{ Convenience } & $x$ & $\triangle$ & $\triangle$ & O & ○ \\
\hline & Frequent manual exchange & Manual control & Manual control & Automated control & Automated control \\
\hline \multirow[t]{2}{*}{ Inexpensiveness } & O & $\triangle$ & $\triangle$ & $x$ & $x$ \\
\hline & & Specialized devices & Specialized devices & Specialized devices & Specialized devices \\
\hline
\end{tabular}

${ }^{a}$ The percentage of time the patient's temperature was out of range more than $0.2{ }^{\circ} \mathrm{C}$ below or above the target temperature

Reference: [49] Hoedemaekers CW, Ezzahti M, Gerritsen A, van der Hoeven JG. Comparison of cooling methods to induce and maintain normo- and hypothermia in intensive care unit patients: a prospective intervention study. Crit Care 2007; 11: R91 
lists rapid infusion of ice-cold IV fluid and ice packs as feasible, safe, and simple introduction methods that do not require any specialized devices $[1,2]$.

In an RCT, the following five cooling methods were compared in 50 ICU patients who required strict TTM, including 16 OHCA patients and 4 IHCA patients: (1) rapid infusion of $30 \mathrm{ml} / \mathrm{kg}$ cold fluids and ice-cold packs (conventional cooling), (2) water-circulating blankets, (3) air-circulating blankets, (4) water-circulating gelcoated pads, and (5) intravascular cooling devices [49] (Table 2). Temperature decline was greater with the water-circulating blankets $\left(1.33^{\circ} \mathrm{C} / \mathrm{h}\right)$, water-circulating gel-coated pads $\left(1.04{ }^{\circ} \mathrm{C} / \mathrm{h}\right)$, and intravascular cooling devices $\left(1.46{ }^{\circ} \mathrm{C} / \mathrm{h}\right)$ compared to conventional cooling $\left(0.32{ }^{\circ} \mathrm{C} / \mathrm{h}\right)$ and the air-circulating blankets $\left(0.18{ }^{\circ} \mathrm{C} / \mathrm{h}\right)$ $(p<0.05)$. Moreover, the percentage of time for which the patient's temperature was more than $0.2{ }^{\circ} \mathrm{C}$ below or above the target temperature was significantly lower with the intravascular cooling device $(3.2 \%)$ than with other methods (water-circulating gel-coated pad, $44.2 \%$; water-circulating blanket, $50.5 \%$; conventional cooling, $69.8 \%$; air-circulating blanket, $74.1 \%$; $p<0.05)$. Based on these findings, an intravascular cooling device may be an efficient way to achieve the target temperature earlier and to maintain a stable temperature.

Two RCTs have been conducted to evaluate the clinical impact of intravascular cooling on outcomes after OHCA. One RCT compared invasive advanced internal cooling $\left(\mathrm{CoolGard}^{\circ}\right)$ with non-invasive advanced external cooling (ArcticSun ${ }^{\circ}$ ) [50], and the other RCT compared invasive advanced internal cooling $\left(\mathrm{CoolGard}^{\star}\right)$ with non-invasive basic external cooling (using fans, cooling tents if possible, and ice packs) [51]. These two RCTs showed no beneficial effects of intravascular cooling on survival or favorable neurological outcomes after OHCA. However, the target temperature was more strictly maintained with intravascular cooling. The time to achieve the target temperature with advanced internal cooling (CoolGard $^{\circ}$ ) was similar to that with advanced external cooling (ArcticSun ${ }^{\circ}$ ) but significantly shorter than that with basic external cooling. Bleeding complications were more frequent with intravascular cooling.

Thus, it appears that intravascular cooling devices are beneficial for reducing time to target temperature and improving strict maintenance of the target temperature, but this does not always lead to improved outcomes. Currently, there is insufficient evidence to recommend any specific cooling method. Therefore, it is necessary to fully understand the advantages and disadvantages of each cooling method and consider which combination of methods is appropriate for each facility.

When TH is initiated, cooling methods that do not require specialized devices, such as rapid infusion of icecold IV fluid and ice packs, as described in the ILCOR guidelines [1,2], may be useful because they can be implemented anytime and anywhere (including pre-hospital, during transport, or during resuscitation) and are safe and inexpensive. Conversely, during the maintenance phase, the selection of a cooling method that matches the available budget, manpower, and equipment of each facility may be desirable.

\section{Rewarming}

According to the ERC guidelines, because plasma electrolyte concentrations and effective intravascular volumes and metabolic rates are likely to change suddenly, it is recommended to perform rewarming slowly [19]. The recommended rate for rewarming in the ERC Hypothermia After Cardiac Arrest Registry (ERC HACA-R) is 0.25$0.5^{\circ} \mathrm{C} / \mathrm{h}[52]$.

In a retrospective cohort study including 128 patients treated with $\mathrm{TH}$ after cardiac arrest, the authors examined rewarming method (active vs. passive), rewarming speed $\left(\geqq 0.5{ }^{\circ} \mathrm{C} / \mathrm{h}\right.$ vs. $<0.5{ }^{\circ} \mathrm{C} / \mathrm{h}$ ), and the relationship between fever $\left(>38^{\circ} \mathrm{C}\right)$ and poor outcomes. The odds ratios for poor outcomes after adjustment for confounders were as follows: active rewarming, 1.51 (95 \% CI 0.64-3.58, $p=$ $0.35)$; rewarming speed $\geqq 0.5{ }^{\circ} \mathrm{C} / \mathrm{h}, 2.61(95 \% \mathrm{CI} 0.88$ 7.73, $p=0.08$ ); fever, 0.64 (95\% CI 0.31-1.30, $p=0.22$ ) [53]. There were no significant associations between rewarming method and outcomes in this study. It is expected that RCTs will also be performed to investigate optimal rewarming methods.

The AHA guidelines recommend treatment of hyperthermia following rewarming of the patient through $\mathrm{TH}$ [18]. This is based on several studies that have shown a relationship between hyperthermia in post-cardiac arrest syndrome (PCAS) and poor outcomes [54-57]. Based on these studies, hyperthermia should be avoided for 48-72 $\mathrm{h}$ after ROSC.

In the Penn Alliance for Therapeutic Hypothermia (PATH) Registry, a multicenter US clinical registry that includes 167 patients who survived $24 \mathrm{~h}$ after post-TTM rewarming, the relationships between rebound pyrexia (defined as temperature $>38{ }^{\circ} \mathrm{C}$ ) and clinical outcomes were examined [58]. After post-TTM rewarming, pyrexia was observed in $41 \%$ of patients, and the median temperature was $38.7^{\circ} \mathrm{C}$. There were no significant differences between the pyrexia group and the no pyrexia group in survival rate ( 54 vs. $52 \%, p=0.88$ ) or favorable neurologic outcome (70 vs. $82 \%, p=0.21$ ). However, when the authors compared marked pyrexia (greater than the median pyrexia of $38.7^{\circ} \mathrm{C}$ ) with no or milder pyrexia (below the median), the survival rate did not differ (40 vs. $56 \%, p=0.16)$, but marked pyrexia was associated with more frequent poor neurological outcomes (58 vs. $80 \%, p=0.04)$. Based on these findings, it may be that there is a relationship between higher pyrexia 
after post-TTM rewarming and more severe brain injury or that there is a threshold temperature above which an effect on outcomes is detectable. However, because their study design can only indicate an association, not a causal relationship, it is difficult to resolve these issues decisively. Further study is necessary to identify the maximum safe temperature after post-TTM rewarming, and the duration for which temperature management should be continued, and the importance of avoiding hyperthermia after completion of rewarming.

\section{Which patients benefit the most from TTM}

In this review, we mainly examined how best to perform TTM after OHCA. However, we also know very little about which patients benefit the most from TTM. What we do know is that TTM seems to have the most impact on favorable outcomes among patients with an initial shockable rhythm [3, 4, 59]. Several studies have examined whether the effectiveness of TTM might depend on the time, such as no-flow time, low-flow time, or total down-time [59-62], or on the severity of anoxicischemic injury [63-65]. Well-designed studies will be required to identify who can benefit the most from TTM.

\section{Conclusions}

It is not yet possible to identify the most appropriate practical method for TTM after OHCA. A recently published large RCT showed no advantage for TTM of $33^{\circ}$ $\mathrm{C}$ in comparison with TTM of $36{ }^{\circ} \mathrm{C}$, but it would be premature to discard the numerous previous studies and the pathophysiology that support the efficacy of TH. On the other hand, this large RCT also confirmed that strict TTM is essential. Although it remains undetermined whether $\mathrm{TH}$ should be performed, it is necessary to surely manage temperature to avoid hyperthermia. RCTs concerning the optimal target temperature, optimal timing of initiation, and optimal duration of treatment are currently in progress. To determine whether $\mathrm{TH}$ is beneficial after cardiac arrest and how best to perform TTM after cardiac arrest, the ongoing RCTs deserve careful attention.

\footnotetext{
Abbreviations

AHA: American Heart Association; Cl: confidence interval; CoSTR: Internatinal Consensus on Cardiopulmonary Resuscitation and Emergency Cardiovascular Care Science with Treatment Recommendations; CPC: Glasgow-Pittsburgh cerebral performance category; ERC: European Resuscitation Council; HR: hazard ratio; ICU: intensive care unit; IHCA: in-hospital cardiac arrest; ILCOR: International Liaison Committee on Resuscitation; NCS: Neurocritical Care Society; NSE: neuron-specific enolase; OHCA: out-of-hospital cardiac arrest; OR: odds ratio; PCAS: post-cardiac arrest syndrome; RCT: randomized controlled trial; ROSC: return of spontaneous circulation; RR: relative risk; $\mathrm{TH}$ : therapeutic hypothermia; TTM: targeted temperature management.
}

\section{Competing of interests}

The authors declare that they have no competing interests.
Received: 4 September 2015 Accepted: 4 February 2016

Published online: 27 April 2016

\section{References}

1. Morrison LJ, Deakin CD, Morley PT, Advanced Life Support Chapter Collaborators, et al. Part 8: advanced life support: 2010 International Consensus on Cardiopulmonary Resuscitation and Emergency Cardiovascular Care Science with Treatment Recommendations. Circulation. 2010;122(16 Suppl 2):S345-421.

2. Deakin CD, Morrison L, Morley PT, Advanced Life Support Chapter Collaborators, et al. Part 8: advanced life support: 2010 International Consensus on Cardiopulmonary Resuscitation and Emergency Cardiovascular Care Science with Treatment Recommendations. Resuscitation. 2010;81 Suppl 1:e93-e174.

3. Hypothermia after Cardiac Arrest Study Group. Mild therapeutic hypothermia to improve the neurologic outcome after cardiac arrest. N Engl J Med. 2002;346:549-56.

4. Bernard SA, Gray TW, Buist MD, et al. Treatment of comatose survivors of out-of-hospital cardiac arrest with induced hypothermia. N Engl J Med. 2002;346:557-63.

5. Arrich J, Holzer M, Havel C, Müllner M, Herkner H. Hypothermia for neuroprotection in adults after cardiopulmonary resuscitation. Cochrane Database Syst Rev. 2012;9:CD004128.

6. Nielsen N, Hovdenes J, Nilsson F, Hypothermia Network, et al. Outcome, timing and adverse events in therapeutic hypothermia after out-of-hospital cardiac arrest. Acta Anaesthesiol Scand. 2009;53:926-34.

7. Nielsen N, Wetterslev J, Cronberg T, Trial Investigators TTM, et al. Targeted temperature management at $33^{\circ} \mathrm{C}$ versus $36^{\circ} \mathrm{C}$ after cardiac arrest. N Engl J Med. 2013;369:2197-206.

8. Perman SM, Goyal M, Neumar RW, Topjian AA, Gaieski DF. Clinical applications of targeted temperature management. Chest. 2014;145:386-93.

9. Polderman $\mathrm{KH}$. Mechanisms of action, physiological effects, and complications of hypothermia. Crit Care Med. 2009;37(7 Suppl):S186-202.

10. Rosomoff HL, Holaday DA. Cerebral blood flow and cerebral oxygen consumption during hypothermia. Am J Physiol. 1954;179:85-8.

11. Milde LN. Clinical use of mild hypothermia for brain protection: a dream revisited. J Neurosurg Anesthesiol. 1992;4:211-5.

12. McCullough JN, Zhang $\mathrm{N}$, Reich DL, et al. Cerebral metabolic suppression during hypothermic circulatory arrest in humans. Ann Thorac Surg. 1999;67:1895-9.

13. Polderman KH. Application of therapeutic hypothermia in the ICU: opportunities and pitfalls of a promising treatment modality. Part 1 : indications and evidence. Intensive Care Med. 2004;30:556-75.

14. Yenari MA, Han HS. Neuroprotective mechanisms of hypothermia in brain ischaemia. Nat Rev Neurosci. 2012;13:267-78.

15. Globus MY, Alonso O, Dietrich WD, Busto R, Ginsberg MD. Glutamate release and free radical production following brain injury: effects of posttraumatic hypothermia. J Neurochem. 1995;65:1704-11.

16. Chi OZ, Liu X, Weiss HR. Effects of mild hypothermia on blood-brain barrier disruption during isoflurane or pentobarbital anesthesia. Anesthesiology. 2001;95:933-8.

17. Jurkovich GJ, Pitt RM, Curreri PW, Granger DN. Hypothermia prevents increased capillary permeability following ischemia-reperfusion injury. J Surg Res. 1988:44:514-21.

18. Peberdy MA, Callaway CW, Neumar RW, American Heart Association, et al. Part 9: post-cardiac arrest care: 2010 American Heart Association Guidelines for Cardiopulmonary Resuscitation and Emergency Cardiovascular Care. Circulation. 2010;122(18 Suppl 3):S768-86.

19. Deakin CD, Nolan JP, Soar J, et al. European Resuscitation Council Guidelines for Resuscitation 2010 Section 4. Adult advanced life support. Resuscitation. 2010;81:1305-52.

20. Rittenberger JC, Polderman KH, Smith WS, Weingart SD. Emergency neurological life support: resuscitation following cardiac arrest. Neurocrit Care. 2012;17 Suppl 1:S21-8.

21. Che D, Li L, Kopil CM, Liu Z, Guo W, Neumar RW. Impact of therapeutic hypothermia onset and duration on survival, neurologic function, and neurodegeneration after cardiac arrest. Crit Care Med. 2011;39:1423-30.

22. Kuboyama K, Safar P, Radovsky A, Tisherman SA, Stezoski SW, Alexander H. Delay in cooling negates the beneficial effect of mild resuscitative cerebral hypothermia after cardiac arrest in dogs: a prospective, randomized study. Crit Care Med. 1993;21:1348-58. 
23. Takata K, Takeda Y, Sato T, Nakatsuka H, Yokoyama M, Morita K. Effects of hypothermia for a short period on histologic outcome and extracellular glutamate concentration during and after cardiac arrest in rats. Crit Care Med. 2005:33:1340-5.

24. Abella BS, Zhao D, Alvarado J, Hamann K, Vanden Hoek TL, Becker LB. Intra-arrest cooling improves outcomes in a murine cardiac arrest model. Circulation. 2004;109:2786-91.

25. Sendelbach S, Hearst MO, Johnson PJ, Unger BT, Mooney MR. Effects of variation in temperature management on cerebral performance category scores in patients who received therapeutic hypothermia post cardiac arrest. Resuscitation. 2012;83:829-34.

26. Mooney MR, Unger BT, Boland $L L$, et al. Therapeutic hypothermia after out-of-hospital cardiac arrest: evaluation of a regional system to increase access to cooling. Circulation. 2011;124:206-14.

27. Wolff B, Machill K, Schumacher D, Schulzki I, Werner D. Early achievement of mild therapeutic hypothermia and the neurologic outcome after cardiac arrest. Int J Cardiol. 2009:133:223-8.

28. Kim F, Olsufka M, Longstreth Jr WT, et al. Pilot randomized clinical trial of prehospital induction of mild hypothermia in out-of-hospital cardiac arrest patients with a rapid infusion of 4 degrees $C$ normal saline. Circulation. 2007;115:3064-70.

29. Kämäräinen A, Virkkunen I, Tenhunen J, Yli-Hankala A, Silfvast T. Prehospita therapeutic hypothermia for comatose survivors of cardiac arrest: a randomized controlled trial. Acta Anaesthesiol Scand. 2009:53:900-7.

30. Hammer L, Vitrat F, Savary D, et al. Immediate prehospital hypothermia protocol in comatose survivors of out-of-hospital cardiac arrest. Am J Emerg Med. 2009;27:570-3

31. Uray T, Malzer R, Vienna Hypothermia After Cardiac Arrest (HACA) Study Group. Out-of-hospital surface cooling to induce mild hypothermia in human cardiac arrest: a feasibility trial. Resuscitation. 2008;77:331-8.

32. Bruel C, Parienti JJ, Marie W, et al. Mild hypothermia during advanced life support: a preliminary study in out-of-hospital cardiac arrest. Crit Care. 2008;12:R31

33. Castrén $M$, Nordberg $P$, Svensson $L$, et al. Intra-arrest transnasal evaporative cooling: a randomized, prehospital, multicenter study (PRINCE: Pre-ROSC IntraNasal Cooling Effectiveness). Circulation. 2010;122:729-36.

34. Bernard SA, Smith K, Cameron P, Rapid Infusion of Cold Hartmanns (RICH) Investigators, et al. Induction of therapeutic hypothermia by paramedics after resuscitation from out-of-hospital ventricular fibrillation cardiac arrest: a randomized controlled trial. Circulation. 2010;122:737-42.

35. Bernard SA, Smith K, Cameron P, Rapid Infusion of Cold Hartmanns Investigators, et al. Induction of prehospital therapeutic hypothermia after resuscitation from nonventricular fibrillation cardiac arrest*. Crit Care Med. 2012;40:747-53.

36. Kim F, Nichol G, Maynard C, et al. Effect of prehospital induction of mild hypothermia on survival and neurological status among adults with cardiac arrest: a randomized clinical trial. JAMA. 2014;311:45-52.

37. Diao M, Huang F, Guan J, et al. Prehospital therapeutic hypothermia after cardiac arrest: a systematic review and meta-analysis of randomized controlled trials. Resuscitation. 2013;84:1021-8.

38. Hunter BR, O'Donnell DP, Allgood KL, Seupaul RA. No benefit to prehospital initiation of therapeutic hypothermia in out-of-hospital cardiac arrest: a systematic review and meta-analysis. Acad Emerg Med. 2014;21:355-64.

39. Yannopoulos D, Zviman M, Castro V, et al. Intra-cardiopulmonary resuscitation hypothermia with and without volume loading in an ischemic model of cardiac arrest. Circulation. 2009;120:1426-35.

40. Garrett JS, Studnek JR, Blackwell T, et al. The association between intra-arrest therapeutic hypothermia and return of spontaneous circulation among individuals experiencing out of hospital cardiac arrest. Resuscitation. 2011;82:21-5.

41. Scolletta S, Taccone FS, Nordberg P, Donadello K, Vincent JL, Castren M. Intra-arrest hypothermia during cardiac arrest: a systematic review. Crit Care. 2012;16:R41.

42. Gluckman PD, Wyatt JS, Azzopardi D, et al. Selective head cooling with mild systemic hypothermia after neonatal encephalopathy: multicentre randomised trial. Lancet. 2005;365:663-70.

43. Shankaran S, Laptook AR, Ehrenkranz RA, National Institute of Child Health and Human Development Neonatal Research Network, et al. Whole-body hypothermia for neonates with hypoxic-ischemic encephalopathy. N Engl J Med. 2005;353:1574-84.

44. Nagao K, Kikushima K, Watanabe K, et al. Early induction of hypothermia during cardiac arrest improves neurological outcomes in patients with out-of-hospital cardiac arrest who undergo emergency cardiopulmonary bypass and percutaneous coronary intervention. Circ J. 2010;74:77-85.

45. Hagioka S, Takeda Y, Takata K, Morita K. Nasopharyngeal cooling selectively and rapidly decreases brain temperature and attenuates neuronal damage, even if initiated at the onset of cardiopulmonary resuscitation in rats. Crit Care Med. 2003;31:2502-8.

46. Busch HJ, Eichwede F, Födisch M, et al. Safety and feasibility of nasopharyngeal evaporative cooling in the emergency department setting in survivors of cardiac arrest. Resuscitation. 2010;81:943-9.

47. Wang H, Olivero W, Lanzino G, et al. Rapid and selective cerebral hypothermia achieved using a cooling helmet. J Neurosurg. 2004;100:272-7.

48. Hachimi-Idrissi S, Corne L, Ebinger G, Michotte Y, Huyghens L. Mild hypothermia induced by a helmet device: a clinical feasibility study. Resuscitation. 2001;51:275-81.

49. Hoedemaekers CW, Ezzahti M, Gerritsen A, van der Hoeven JG. Comparison of cooling methods to induce and maintain normo- and hypothermia in intensive care unit patients: a prospective intervention study. Crit Care. 2007;11:R91.

50. Pittl U, Schratter A, Desch $\mathrm{S}$, et al. Invasive versus non-invasive cooling after in- and out-of-hospital cardiac arrest: a randomized trial. Clin Res Cardiol. 2013;102:607-14.

51. Deye N, Cariou A, Girardie P, Clinical and Economical Impact of Endovascular Cooling in the Management of Cardiac Arrest (ICEREA) Study Group, et al. Endovascular versus external targeted temperature management for patients with out-of-hospital cardiac arrest: a randomized, controlled study. Circulation. 2015;132:182-93.

52. Arrich J, European Resuscitation Council Hypothermia After Cardiac Arrest Registry Study Group. Clinical application of mild therapeutic hypothermia after cardiac arrest. Crit Care Med. 2007;35:1041-7.

53. Bouwes A, Robillard LB, Binnekade JM, et al. The influence of rewarming after therapeutic hypothermia on outcome after cardiac arrest. Resuscitation. 2012;83:996-1000.

54. Takino M, Okada Y. Hyperthermia following cardiopulmonary resuscitation. Intensive Care Med. 1991;17:419-20.

55. Zeiner A, Holzer M, Sterz F, et al. Hyperthermia after cardiac arrest is associated with an unfavorable neurologic outcome. Arch Intern Med. 2001;161:2007-12.

56. Takasu A, Saitoh D, Kaneko N, Sakamoto T, Okada Y. Hyperthermia: is it an ominous sign after cardiac arrest? Resuscitation. 2001;49:273-7.

57. Langhelle A, Tyvold SS, Lexow K, Hapnes SA, Sunde K, Steen PA. In-hospital factors associated with improved outcome after out-of-hospital cardiac arrest. A comparison between four regions in Norway. Resuscitation. 2003:56:247-63.

58. Leary M, Grossestreuer AV, lannacone $\mathrm{S}$, et al. Pyrexia and neurologic outcomes after therapeutic hypothermia for cardiac arrest. Resuscitation. 2013:84:1056-61.

59. Kim WY, Giberson TA, Uber A, Berg K, Cocchi MN, Donnino MW. Neurologic outcome in comatose patients resuscitated from out-of-hospital cardiac arrest with prolonged downtime and treated with therapeutic hypothermia. Resuscitation. 2014:85:1042-6.

60. Testori C, Sterz F, Holzer M, et al. The beneficial effect of mild therapeutic hypothermia depends on the time of complete circulatory standstill in patients with cardiac arrest. Resuscitation. 2012;83:596-601.

61. Drennan IR, Lin S, Thorpe KE, Morrison LJ. The effect of time to defibrillation and targeted temperature management on functional survival after out-ofhospital cardiac arrest. Resuscitation. 2014;85:1623-8.

62. Kaneko T, Kasaoka S, Nakahara T, J-PULSE-Hypo Investigators, et al. Effectiveness of lower target temperature therapeutic hypothermia in post-cardiac arrest syndrome patients with a resuscitation interval of $\leq 30$ min. J Intensive Care. 2015;3:28.

63. Natsukawa T, Sawano H, Natsukawa M, et al. At what level of unconsciousness is mild therapeutic hypothermia indicated for out-of-hospital cardiac arrest: a retrospective, historical cohort study. J Intensive Care. 2015;3:38.

64. Starodub R, Abella BS, Grossestreuer AV, et al. Association of serum lactate and survival outcomes in patients undergoing therapeutic hypothermia after cardiac arrest. Resuscitation. 2013;84:1078-82.

65. Lee TR, Kang MJ, Cha WC, et al. Better lactate clearance associated with good neurologic outcome in survivors who treated with therapeutic hypothermia after out-of-hospital cardiac arrest. Crit Care. 2013;17:R260. 